\title{
E-LEARNING DALAM PERSEPSI MAHASISWA
}

\author{
Much. Fuad Saifuddin \\ Pendidikan Biologi FKIP, Universitas Ahmad Dahlan \\ fuad.saifuddin@pbio.uad.ac.id
}

\begin{abstract}
The purpose of this research is to know the students' perceptions of e-learning and various aspects that students need when using e-learning. This descriptive research was done by questionnaire in collecting the data. The source of the data was students of biology of FKIP UAD. The result of the analysis shows that 98.8\% of students know e-learning, 86.3\% support e-learning implementation, and $77 \%$ expressed satisfaction with the implementation of learning with e-learning. As a result, the students' perceptions of e-learning are beneficial, can improve motivation, make it easier to understand the material, to help the readiness in the lecture. Based on e-learning analysis in terms of students have high accessibility is $91 \%$, with light use $83 \%$. Good appraisal Student perception of e-learning, giving a big role in the implementation of learning with e-learning, which can be done with the pattern of blended learning as a form of learning that collaborate e-learning with face to face.
\end{abstract}

Keywords: accessibility, e-learning, motivation, satisfaction, student perception

\begin{abstract}
Abstrak. Tujuan dari penelitian ini untuk mengetahui persepsi mahasiswa terhadap e-learning dan berbagai aspek yang dibutuhkan mahasiswa saat menggunakan e-learning. Penelitian deskriptif ini dilakukan dengan teknik kuesioner terhadap mahasiswa pendidikan biologi FKIP UAD angkatan 2015 dan 2016 yang dipilih secara acak; dan teknik deskriptif digunakan sebagai alat analisisnya. Hasil analisis menunjukkan, mahasiswa 98,8\% mahasiswa mengetahui e-learning, 86,3\% mendukung pelaksanaan e-learning, dan $77 \%$ menyatakan puas dengan pelaksanaan pembelajaran dengana e-learning. Selaiin itu, menghasilkan persepsi mahasiswa e-learning bermanfaat, dapat meningkatkan motivasi, memudahkan memahami materi, membantu kesiapan dalam perkuliahan. Berdasarkan analisis e-learning dalam pengertian mahasiswa memiliki aksesibilitas yang tinggi yaitu 91\%, dengan penggunaan ringan $83 \%$. Penilaian baik Persepsi mahasiswa terhadap e-learning, memberikan peran yang besar dalam pelaksanaan pembelajaran dengan e-learning, yang dapat dilakukan dengan pola blendedlearning sebagai bentuk pembelajaran yang mengkolaborasikan e-learning dengan tatap muka.
\end{abstract}

Kata kunci: Aksesibilitas, e-learning, kepuasan, motivasi, persepsi mahasiswa

\section{Pendahuluan}

Internet saat ini telah menjadi bagian yang tidak terpisahkan dari gaya hidup berbagai kelompok masyarakat Indonesia. Data hasil survei yang dilakukan oleh Asosiasi Penyelenggara Jaringan Internet Indonesia (APJII) pada tahun 2016 menunjukkan bahwa kalangan mahasiswa merupakan pengguna internet terbesar di Indonesia dengan 89,7\%, dan urutan kedua pelajar dengan 69,8\% namun akses terhadap laman pendidikan masih sangat kurang. Sebuah permasalahan yang perlu untuk disikapi oleh para pendidik dengan mengarahkan mahasiswa/peserta didik untuk lebih menggunakan internet dalam ranah pendidikan.

Kelas virtual atau lebih dikenal dengan e-learning, merupakan salah satu bentuk penggunaan internet yang dapat meningkatkan peran mahasiswa/peserta didik dalam 
proses pembelajaran. Berbagai layanan e-learning telah tersedia baik yang dikelola mandiri oleh institusi dengan menggunakan Learning Management System (LMS) maupun yang disediakan secara bebas oleh pihak ketiga. E-learning berperan untuk melengkapi kelas konvensional (secara tatap muka) bukan menggantikan kelas konvensional (Shank, 2008). Menurut Novak (dalam Balaji, Al-Mahri, \& Malathi, 2016) dengan menggunakan e-learning dapat meningkatkan interaktivitas dan efisiensi belajar karena memberikan mahasiswa potensi yang lebih tinggi untuk berkomunikasi lebih banyak dengan dosen, rekan, dan mengakses lebih banyak materi pembelajaran.

Kemauan seseorang dalam menggunakan produk teknologi sangat dipengaruhi oleh persepsi. Persepsi merupakan suatu proses yang dimulai dari penggunaan panca indera dalam menerima stimulus, kemudian diorganisasikan dan diinterpretaikan sehingga memiliki pemahaman tentang apa yang diindera (Nugroho, 2012)

Universitas Ahmad Dahlan telah lama memiliki e-learning yang dikembangkan dengan menggunalan LMS Moodle dan telah digunakan sebagai salah satu bentuk pembelajaran yang diakui oleh pimpinan universitas. Dosen di lingkungan pendidikan biologi FKIP UAD telah menggunakan e-learning, baik dalam bentuk unggah dokumen (RPS, Materi perkuliahan) maupun dalam aktivitas pembelajaran secara daring seperti diskusi, dan pengumpulan tugas. Pelaksanaan pembelajaran melalui e-learning perlu untuk dikaji lebih dalam dengan melihat respon mahasiswa terhadap proses pembelajaran berbasis e-learning, sehingga dapat diketahui bentuk pembelajaran berbasis e-learning yang diinginkan oleh mahasiswa. Penelitian ini bertujuan untuk mengetahui persepsi mahasiswa pendidikan biologi FKIP UAD terhadap pembelajaran berbasis e-learning.

\section{Metode}

Penelitian ini termasuk dalam penelitian deskriptif, dengan melakukan survei terhadap mahasiswa pendidikan biologi FKIP UAD. Teknik pengumpulan data dengan menggunakan angket, dengan sampel mahasiswa angkatan 2015 dan 2016 yang dipilih secara acak. Tahapan yang dilakukan dalam penelitian ini:

- Pertama, penyusunan instrumen angket yang akan digunakan untuk pengumpulan data. Informasi yang termuat dalam angket antara lain: pengetahuan tentang e-learning, konten, aksesibilitas, kebermanfaatan, kepuasan penggunaan e-learning.

- Kedua, angket yang telah disusun diuji validitas dengan menggunakan pendapat ahli yang dilakukan oleh dua ahli instrumen yang juga memahami e-learning.

- Ketiga, mengumpulkan data dengan angket yang telah divalidasi dari mahasiswa pendidikan biologi angkatan 2015 dan 2016 yang dipilih secara acak sebanyak 95 mahasiswa.

- Data yang diperoleh dari mahasiswa berupa data kualitatif dan kuantitatif, yang kemudian dilakukan analisis secara deskriptif.

\section{Hasil dan pembahasan}

Data yang diperoleh melalui angket berupa respon persepsi mahasiswa terhadap e-learning, dipersentasekan berdasarkan aspek yang diamati serta paparan secara deskriptif kualitatif berdasarkan respon yang disampaikan.

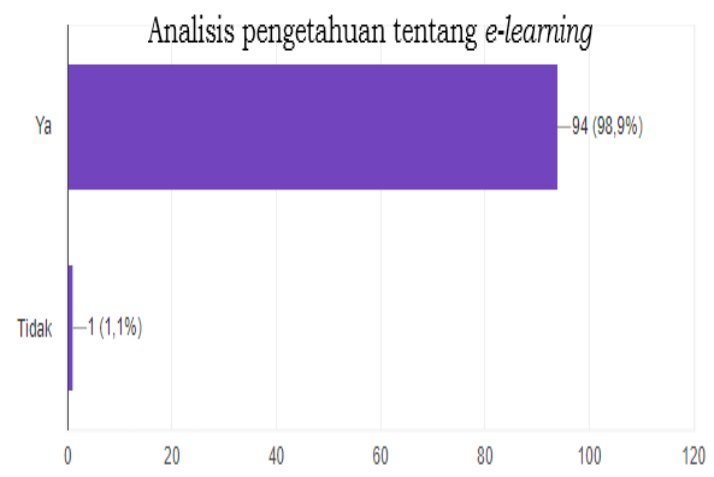

Gambar 1. Analisis pengetahuan tentang e-learning 
Menurut pemahaman Anda, apakah yang Anda ketahui tentang E-Learning

E-Learning membantu mahasiswa dapat sebagai sarana belajar online, mengakses tugas-tugas yang diberikan dosen.

Elearning merupakan sarana pembelajaran di luar kelas

E-learning adalah salah satu perangkat yang digunakan oleh dosen untuk kegiatan pembelajaran dalam hal membagi materi perkuliahan atau memudahkan untuk mengupload tugas

Laman yg menyediakan banyak fungsi salah satunya mampu dimanfaatkan dalam perkuliahan

Suatu aplikasi yang memudahkan mahasiswa melaksnakan perkuliahan dan tugas secara online

Aplikasi pembelajaran secara online

E-learning merupakan salah satu media belajar dengan menggunakan jaringan internet

Elearning memudahkan dalam menyampaikan informasi

Proses belajar mengajar dengan memanfaatkan teknologi informasi

E-Learning merupakan pembelajaran jarak jauh yang memanfaatkan teknologi komputer, jaringan komputer dan/atau Internet. E-

Learning memungkinkan pembelajar untuk belajar melalui komputer di tempat mereka masing-masing tanpa harus secara fisik pergi mengikuti pelajaran/perkuliahan di kelas.

E-learning merupakan fasilitas belajar/berdiskusi secara online

Suatu sistem yang disusun untuk mempermudah pembelajaran yang memanfaatkan teknologi informasi dalam proses belajar mengajar

E-Learning adalah tempat untuk memberikan informasi serta sebagai konsep pendidikan yang menggunakan teknologi dalam belajar mengajar.

\section{Gambar 2. Contoh Pengetahuan Mahasiswa tentang E-learning}

Berdasarkan data angket diperoleh informasi pengetahuan tentang e-learning sebanyak $98,8 \%$ mahasiswa menyatakan mengetahui e-learning, seperti yang tertera dalam gambar 1 .

Analisis pada gambar 1 ditunjang dengan berbagai deskripsi pengetahuan mahasiswa tentang e-learning, seperti yang tertera dalam gambar 2.

Berdasarkan pendapat mahasiswa pada gambar 2, dapat dinyatakan mahasiswa mendefinisikan e-learning sebagai suatu pembelajaran yang dilakukan secara daring, baik berupa akses bahan belajar, pengumpulan tugas dan diskusi. Pendapat tersebut sesuai dengan definisi e-learning menurut Hamid (2001) yang menyatakan dalam e-learning antara penyedia pembelajaran (pendidik) dengan peserta didik (mahasiswa) dipisahkan oleh dunia maya.

Jenis platform e-learning yang ada saat ini sangat beragam, pada angket yang dikembangkan memuat beberapa e-learning yang sering digunakan di Indonesia. Hasil analisis jenis e-learning yang pernah digunakan mahasiswa pendidikan biologi FKIP UAD (gambar 3), menunjukkan Schoology paling banyak digunakan yaitu 42 mahasiswa, kemudian edmodo sebanyak 39 mahasiswa dan google clasroom sebanyak 17 mahasiswa. Moodle yang merupakan sistem e-learning yang digunakan di Universitas Ahmad Dahlan digunakan oleh 10 mahasiswa, hal ini dikarenakan mahasiswa belum mengetahui berbagai jenis platform e-learning dan di dalam angket tidak disebutkan keterangan bahwa e-learning yang dikelola Universitas Ahmad Dahlan menggunakan moodle.

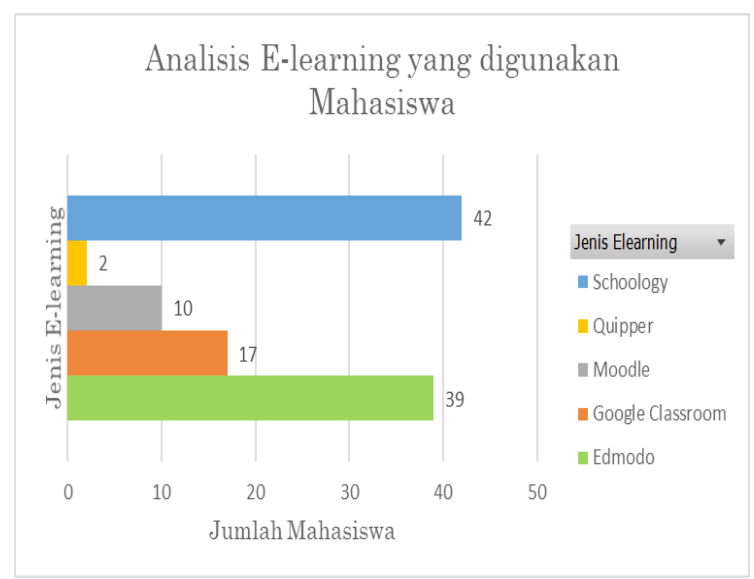

Gambar 3. Analisis Jenis E-learning yang Pernah Digunakan Mahasiswa

Pada aspek pelaksanaan kuliah dengan e-learning diperoleh data dari mahasiswa sebanyak $86,3 \%$ menyatakan setuju, dan $13,7 \%$ mahasiswa menyatakan tidak setuju terhadap pelaksanaan perkuliahan dengan menggunakan e-learning seperti terlihat pada gambar 4. 


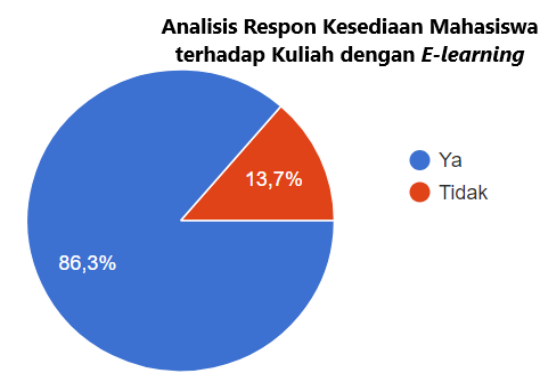

Gambar 4. Analisis Respon Kesediaan Mahasiswa terhadap Kuliah dengan E-learning

Hasil penelitian serupa menyatakan mahasiswa menghendaki pelaksanaan perkuliahan dengan e-learning secara penuh (Muzid \& Munir, 2005). Peran teknologi pendidikan merupakan efek dari perkembangan teknologi yang mempengaruhi akademisi untuk mengubah pembelajarannya (Donnelly \& McSweeney, 2009) hal ini sesuai dengan analisis data pada gambar 4 yang menunjukkan perlunya e-learning dalam pembelajaran di era digital. Menurut walker (dalam Garraway-Lashley, 2014) ketersediaan teknologi yang digunakan secara interaktif dengan diskusi dan panduan dapat menjadi alat untuk pengembangan keterampilan berpikir tingkat tinggi. Hal ini sangat sesuai dengan bentuk pembelajaran dengan menggunakan e-learning, dalam e-learning mahasiswa mempunyai banyak kesempatan untuk menggali informasi lebih dalam melalui diskusi dan panduan materi yang diberikan oleh dosen.

Hasil penelitian Ling (2007) menunjukkan tiga aspek kehadiran yaitu kognitif, pengajaran, dan kehadiran sosial dapat dicapai secara online. Osguthorpe dan Graham (2003) (dalam Graham, 2006) The American Society for Training and Developnment identified blended learning as one of the top ten trends to emerge in the knowledge delivery industry (Rooney, 2003 mengidentifikasi enam alasan perlu menggunakan blended learning yang merupakan salah satu bentuk dari e-learning: (1) kekayaan pedagogis, (2) akses terhadap pengetahuan, (3) interaksi sosial, (4) kenyamanan pribadi, (5) efektivitas biaya, dan (6) kemudahan revisi materi.
E-learning memberikan manfaat bagi mahasiswa dan dosen. Bagi mahasiswa, e-learning merupakan alternatif belajar dibandingkan pembelajaran konvensional dosen, dimana pembelajaran dapat berlangsung di luar ruang kuliah, membentuk kemandirian belajar, membantu menjadikan belajar sebagai belajar sepanjang hayat dan mendorong untuk berinteraksi antara siswa satu dengan yang lain. Sedangkan bagi dosen, e-learning mengubah gaya mengajar yang berdampak pada profesionalitas kerja, memberi peluang menilai siswa dan mengevaluasi pembelajaran setiap siswa dan mengeksplorasi diri secara efisien (Singh, O 'donoghue, \& Worton, 2005).

Pembelajaran melalui e-learning memerlukan desain yang jelas, diantaranya terkait dengan komponen e-learning. Menurut Kelly \& Nanjiani (dalam Wicaksono, 2015) sebuah e-learning harus memiliki tiga komponen dasar yang terdiri dari e-communication (pengkomunikasian materi), e-training (pendekatan sistem LMS) dan e-assessment (penilaian untuk indikator hasil belajar). Hasil analisis komponen e-learning yang memperlihatkan lebih dari 90\% mahasiswa menyatakan perlu adanya beberapa komponen: 1) komponen instruksional pembelajaran di e-learning, 2) komponen adanya rencana pembelajaran di kelas, 3) komponen sumber belajar dan bahan ajar. Hasil analisis komponen instruksional menunjukkan 97\% mahasiswa setuju dengan adanya instruksional pembelajaran dalam e-learning.

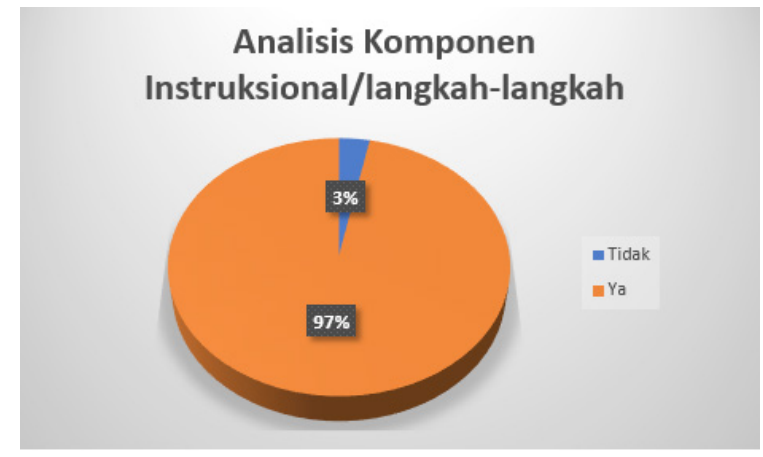

Gambar 5. Analisis komponen instruksional dalam e-learning 
Komponen instruksional merupakan rangkaian langkah-langkah belajar yang akan dilakukan melalui e-learning, sehingga mahasiswa dapat belajar mandiri secara terstruktur terlebih saat mahasiswa baru pertama kali menggunakan e-learning. Selain itu, instruksional dapat membantu proses tercapainya tujuan pembelajaran yang direncanakan oleh dosen.

Hasil yang sama terlihat pada analisis komponen rencana pembelajaran di kelas, komponen ini memberikan manfaat untuk memberikan informasi (gambaran) aktivitas pembelajaran yang akan dilakukan di dalam kelas. Sehingga e-learning berperan bukan menggantikan pembelajaran secara tatap muka tetapi mengkombinasikan antara pembelajaran melalui e-learning dengan pembelajaran secara tatap muka. Hasil analisis memperlihatkan 96\% mahasiswa setuju dengan perlu adanya komponen informasi aktivitas pembelajaran yang akan dilakukan di dalam kelas.

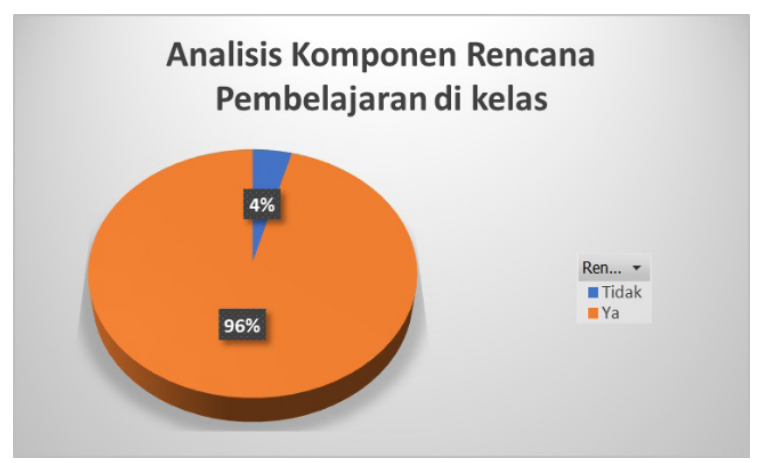

Gambar 6. Analisis Komponen Rencana Pembelajaran di kelas

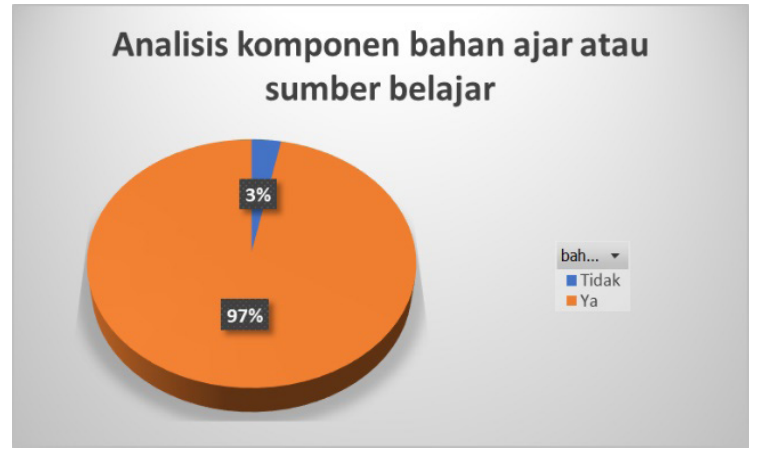

Gambar 7. Analisis komponen bahan ajar atau sumber belajar
Analisis komponen yang ketiga terkait dengan sumber belajar dan bahan ajar, hasil analisis memperlihatkan 97\% mahasiswa menyatakan perlu adanya sumber belajar atau bahan ajar yang disediakan dalam e-learning.

Sumber belajar atau bahan ajar dapat mendukung kesiapan mahasiswa dalam proses pembelajaran. Sumber belajar atau bahan ajar dapat disajikan dalam berbagai bentuk, seperti: handbook, modul, gambar, video, audio yang disesuaikan dengan materi yang akan disampaikan. Mengunggah catatan perkuliahan dan file presentasi dosen (bahan ajar) ke dalam laman e-learning merupakan cara yang umum digunakan dan sangat efektif untuk memberi mahasiswa akses e-learning secara berkelanjutan (Bath \& Bourke, 2010), sehingga mahasiswa dapat mengulang kembali materi yang telah dipelajari setiap waktu. Kualitas konten merupakan hal yang sangat penting dalam e-learning, serta konten juga harus memiliki keramahan terhadap pengguna (Balaji et al., 2016). Konten multimedia interaktif dapat meningkatkan motivasi (Triyanti, 2015), hal ini sangat sesuai untuk menjadi konten dalam e-learning karena memuat aspek visual, audio dan audiovisual.

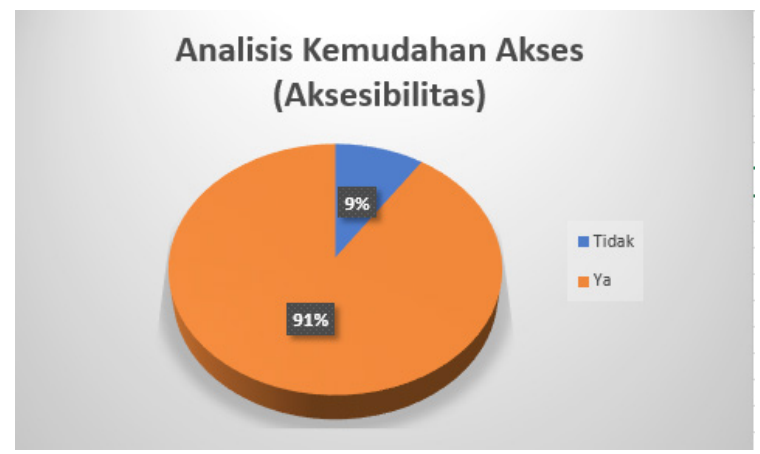

Gambar 8. Analisis Aksesibilitas e-learning

Pada aspek kemudahan akses, hasil analisis memperlihatkan 91\% mahasiswa menyatakan e-learning mudah untuk diakses (gambar 8).Aksesibilitas merupa-kan tingkat kenyamanan seseorang untuk mencapai tujuan yang berhubungan dengan perilaku 
komunikasi (Sapari, Saleh, \& Maksum, 2009). Sebagian besar mahasiswa mengakses e-learning dengan menggu-nakan web browser baik dari smarthpone maupun laptop, hal ini dikarenakan dalam prosesnya belum dapat diselaraskan dengan android (google playstore).

Aspek kemudahan dalam penggunaan, berdasarkan hasil analisis diperoleh $83 \%$ mahasiswa menyatakan e-learning mudah untuk digunakan, sedangkan 17\% mahasiswa menyatakan tidak mudah untuk digunakan (gambar 9). Hal ini dapat disebabkan oleh mahasiswa yang belum terbiasa dalam menggunakan e-learning, serta masih minimnya dosen yang menggunakan e-learning sehingga mahasiswa tidak secara rutin menggunakan e-learning dalam proses pembelajaran. Selain itu, persepsi seseorang terhadap e-learning mempengaruhi kemauan dalam menggunakannya atau tidak, dan kemudahan seseorang dalam menggunakan teknologi (e-learning) akan memberikan pengaruh pada sikap pengguna (Aziz, Al Musadieq, \& Susilo, 2013)Fakultas Ilmu Administrasi Universitas Brawijaya Malang angkatan 2011 ABSTRACT The research aims to: $(1$

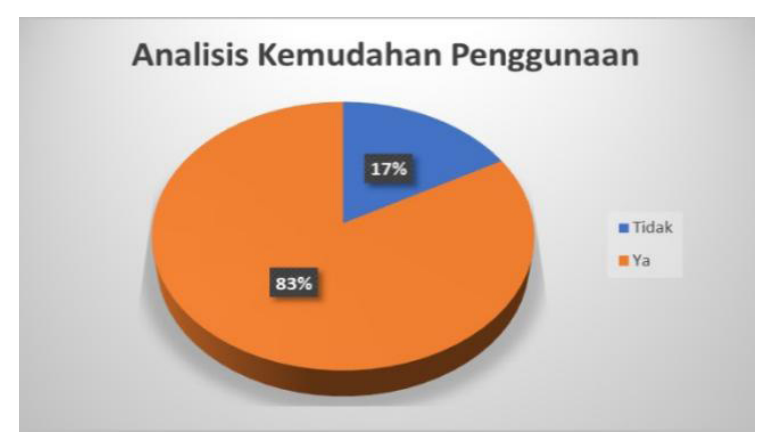

Gambar 9. Hasil analisis kemudahan penggunaan e-learning

Berdasarkan segi kebermanfaatan penggunaan e-learningdalam proses pembelajaran, hasil analisis diperoleh 97\% mahasiswa memberikan respon bahwa e-learning memberikan manfaat dalam proses pembelajaran. Sehingga dapat dinyatakan e-learning memberikan manfaat yang signifikan terhadap proses pembelajaran.

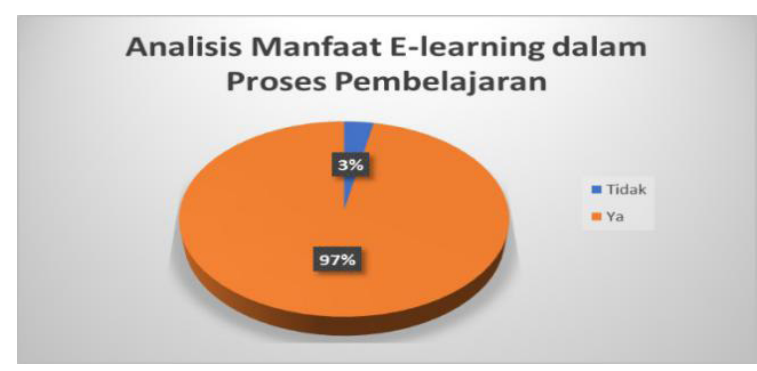

Gambar 10. Analisis manfaat E-learning dalam proses pembelajaran

Aspek yang dianalisis dalam cakupan kebermanfaatan antara lain: membantu kesiapan dalam perkuliahan, membantu belajar mandiri, meningkatkan motivasi, memudahkan dalam mempelajari materi. Hasil analisis tersaji pada gambar 11 .

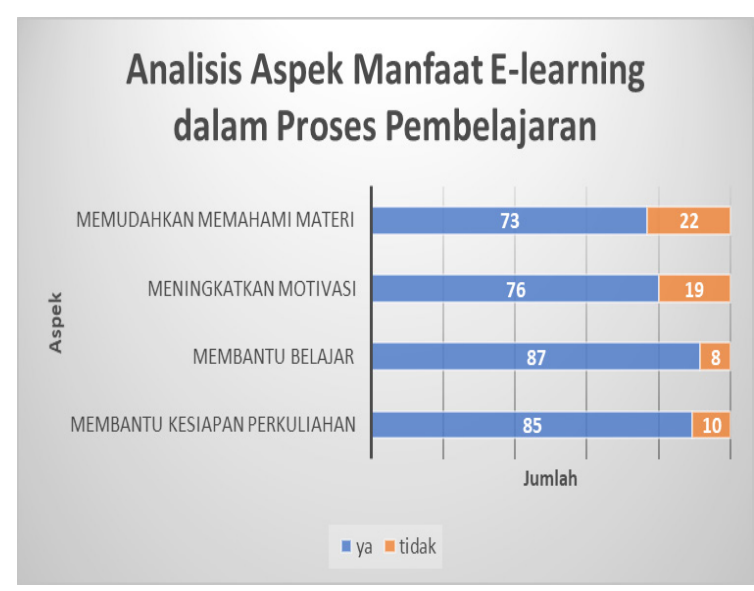

Gambar 11. Hasil analisis aspek manfaat e-learning dalam proses pembelajaran

Mahasiswa menyatakan e-learning dapat membantu dalam persiapan kuliah, dengan model blended learning pola mahasiswa dapat mengakses materi sebelum masuk kelas dan mengetahui gambaran aktivitas yang akan dilakukan dengan mempelajari instruksi maupun desain pembelajaran yang tersedia pada e-learning, sehingga materi dapat digunakan untuk belajar secara mandiri dan dosen akan lebih dapat melakukan eksplorasi pembelajaran karena mahasiswa telah 
memiliki kesiapan terhadap pembelajaran yang akan dilakukan.

E-learning membantu mahasiswa untuk mempelajari materi secara mandiri sebelum masuk kelas, dengan mempelajari materi yang disediakan melalui e-learning dapat meningkatkan motivasi mahasiswa dalam proses pembelajaran di dalam kelas. Pembelajaran dengan E-learning berbeda dengan pembelajaran secara konvensional, dimana dalam pembelajaran dengan e-learning guru tidak berperan sebagai sumber informasi utama yang menyalurkan informasi kepada siswa (Jayawardana, 2017).

\section{ANALISIS KEPUASAN PENGGUNAAN E-LEARNING}

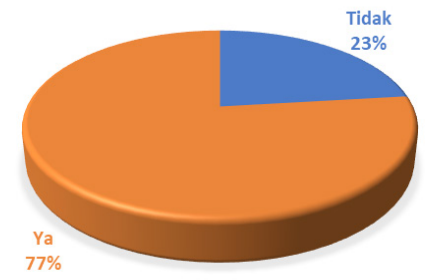

Gambar 12. Analisis Kepuasan Penggunaan E-learning UAD

Hasil analisis kepuasan mahasiswa dalam menggunakan e-learning (dalam hal ini e-learning UAD), diperoleh hasil $77 \%$ mahasiswa menyatakan puas setelah menggunakan e-learning, dan $23 \%$ mahasiswa menyatakan tidak puas seperti terlihat pada gambar 12 .

\section{Simpulan}

Mahasiswa memiliki persepsi yang baik terhadap e-learning, hal ini dipengaruhi oleh pengetahuan dan pengalaman mahasiswa dalam menggunakan e-learning. Mahasiswa menunjukkan kesediannya melakukan pembelajaran dengan e-learning sebesar $86,3 \%$, selain itu mahasiswa mendukung dalam konten e-learning terdapat instruksional yang harus dilakukan dengan e-learning, gambaran pembelajaran yang akan dilakukan di kelas, serta materi yang dapat dipelajari sebelum pembelajaran secara tatap muka. Tingkat kepuasan mahassiswa dalam penggunaan e-learning mencapai $77 \%$. Perlunya dikembangkan pembelajaran dengan mengkombinasikan e-learning dengan model pembelajaran dan bahan ajar yang sesuai dengan karakteristik materi, sehingga penggunaan e-learning dapat lebih dimaksimalkan dan memberikan bekal kepada mahasiswa saat bekerja sebagai seorang guru di era digital.

\section{Daftar Pustaka}

Aziz, A. L., Al Musadieq, M., \& Susilo, H. (2013). Pengaruh Kemudahan Penggunaan Terhadap Kemanfaatan pada Sikap Pengguna E-Learning. Jurnal Administrasi Bisnis, 6(2). Retrieved from https://media.neliti.com/media/publications/78252-ID-pengaruhkemudahan-penggunaan-terhadap-k.pdf

Balaji, R., Al-Mahri, F., \& Malathi, R. (2016). A Perspective Study on Content Management in E-Learning and M-Learning. eprint arXiv:1605.02093. Retrieved from http://arxiv. org/abs/1605.02093

Bath, D., \& Bourke, J. (2010). Getting Started with Blended Learning. Queensland: Griffith University. Retrieved from http://tdu.nmmu.ac.za/Blended-Learning

Donnelly, R., \& McSweeney, F. (2009). Applied E-Learning and E-Teaching in Higher Education. Applied E-Learning and E-Teaching in Higher Education. https://doi. org/10.4018/978-1-59904-814-7

Garraway-Lashley, Y. (2014). Integrating computer technology in the teaching of Biology. International Journal Of Biology Education, 3(2). https://doi.org/10.20876/ijobed.93986

Graham, C. R. (2006). Blended Learning Systems:Definition, Current Trends, and Future 
Directions. In Handbook of blended learning Global perspectives local designs (pp. 3-21). San Francisco: CA: Wiley. https://doi.org/10.2307/4022859

Hamid, A. A. (2001). e-Learning: Is it the "e" or the learning that matters? The Internet and Higher Education, 4(3-4), 311-316. https://doi.org/10.1016/S1096-7516(01)00072-0

Jayawardana, H. B. A. (2017). Paradigma Pembelajaran Biologi di Era Digital. JURNAL BIOEDUKATIKA, 5(1), 12-17. https://doi.org/http://dx.doi.org/10.26555/bioedukatika. v5i1.5628

Ling, L. H. (2007). Community of inquiry in an online undergraduate information technology course. Journal of Information Technology Education, 6, 153-168. https://doi.org/ Article

Muzid, S., \& Munir, M. (2005). Persepsi Mahasiswa Dalam Penerapan e-Learning sebagai Aplikasi Peningkatan Kualitas Pendidikan (Studi Kasus Pada Universitas Islam Indonesia). In Seminar Nasional Aplikasi Teknologi Informasi 2005 (SNATI 2005) (Vol. 2005, p. 8). Yogyakarta.

Nugroho, S. (2012). PROFESIONALISME GURU SD NEGERI SE-KECAMATAN WARUNGASEM KABUPATEN BATANG Suatu tinjauan aspek persepsi guru tentang kepemimpinan kepala sekolah dan motivasi berprestasi guru. Jurnal VARIDIKA, 24(2), 135-146. Retrieved from http://journals.ums.ac.id/index.php/varidika/article/ view/710/441

Sapari, Y., Saleh, A., \& Maksum. (2009). Pemanfaatan Media Komunikasi Prima Tani, Aksesibilitas Kelembagaan Tani, dan Persepsi Petani tentang Teknologi Agribisnis Industrial Pedesaan. Jurnal Komunikasi Pembangunan, 7(1). Retrieved from http:// ilkom.journal.ipb.ac.id/index.php/jurnalkmp/article/view/5679/4308

Shank, P. (2008). Thinking Critically to Move e-learning Forward. In S. Carliner \& P. Shank (Eds.), The e-Learning handbook: past promises, present challenges. San Francisco: Pfeiffer.

Singh, G., O 'donoghue, J., \& Worton, H. (2005). A Study Into The Effects Of eLearning On Higher Education. Journal Journal of University Teaching \& Learning Practice, 2(1). Retrieved from http://ro.uow.edu.au/jutlp

Triyanti, M. (2015). Pengembangan Multimedia Interaktif pada Materi Sistem Saraf untuk Meningkatkan Motivasi dan Hasil Belajar Siswa SMA Kelas XI. JURNAL BIOEDUKATIKA, 3(2), 9-14. https://doi.org/http://dx.doi.org/10.26555/bioedukatika. v3i2.4148

Wicaksono, S. R. (2015). Computer Supported Collaborative Learning Berbasis Blog. Malang: Seribu Bintang. 